\title{
The rebirth of Kairos Theology and its implications for Public Theology and Citizenship in South Africa
}

\section{Clint Le Bruyns ${ }^{1}$}

\begin{abstract}
This article explores the relationship between kairos theology and public theology, placing a particular emphasis on kairos aspects such as contextuality, criticality and change. The article draws from and reflects on the dialogue between South African and Palestinian kairos theologies, the more recent Kairos South Africa movement and the shackdwellers' movement Abahlali baseMjondolo in order to describe a public theology marked by responsibility and contextuality.
\end{abstract}

Keywords: Kairos; Public Theology; Palestine; Abahlali baseMjondolo

\section{Kairos Theology?}

Kairos theology is rightly noted as a brand of liberation theology in and beyond South Africa. Vuyani Vellem puts it well: "Black Theology in South Africa, Kairos Theology, Black Theology in America, Latin American Liberation Theology, Minjung, Dalit, Feminist Theology, African Theology, Contextual Theology and Womanist Theology - all use the category of liberation to define their task, purpose and methodology. All of them, originating from different contexts, symbolize a global, 'worldly' expression of the liberation motif for another possible world." tive expectancy" to refer to the importance of the symbol of the Kairos in public life. ${ }^{3}$

1 Clint Le Bruyns is Director and Senior Lecturer: Theology and Development Programme, within the School of Religion, Philosophy and Classics at the University of KwaZulu-Natal, South Africa. His major areas of expertise are in public theology, economic ethics, theology of work, ethical leadership, and the role of the church in development praxis. In addition to the publication of various popular and scholarly articles, he co-edited two books: The Humanization of Globalization (Germany, 2008) and Ragbag Theologies (South Africa, 2009). He is currently co-editing a book on Pedagogical Liberation? Shifting Perceptions on Palestine-Israel. E-mail: lebruns@ukzn.ac.za

2 Vuyani S Vellem, The Symbol of Liberation in South African Public Life: A Black Theological Perspective. Unpublished PhD thesis, University of Pretoria, April 2007, 83. Available online [internet] at: http://upetd.up.ac.za/thesis/available/etd-10232007-161813/unrestricted/02chapters3-4.pdf [accessed 18/03/2012].

3 Vellem, The Symbol of Liberation in South African Public Life, 99. For a more complex discussion, see also Vuyani S Vellem, "Prophetic Theology in Black Theology, with special reference to the Kairos document” in HTS Teologiese Studies/Theological Studies 66(1), Art. \#800, 6 pages. D0I: 10.4102/ hts.v66i1.800. 
In South Africa, kairos theology tends to be relegated to the apartheid era. It is a prophetic theology for a time of struggle. John de Gruchy describes South African theology as comprising 'theologies of the struggle' and 'post-apartheid theologies'. He places the kairos paradigm under 'prophetic theology' as one of the key theologies of the struggle for liberation. ${ }^{5}$

Its liberational orientation, however, cannot be limited to the South African struggle against apartheid. As we celebrate the South African Kairos Document of $1985 / 1986,{ }^{6}$ it is clear what a tremendous impact this theological tradition has exerted on various other settings and situations. ${ }^{7}$ It facilitated prophetic praxis in relation to different spheres of public life - politics, economics, civil society, and public opinion formation. ${ }^{8}$ Most recently, it is a theological tradition which resulted in the Palestinian Kairos Document of 2009. ${ }^{9}$ Against the background of the kairos documents, coupled with many reflections on the nature and meaning of kairos theology, for me it is a theological tradition (rather than a theology itself) in which the dimensions of contextuality, criticality and change are specially discernible. ${ }^{10}$

4 John de Gruchy, "South African Theology" in William Dyrness and Veli-Matti Kärkkäinen (eds), Global Dictionary of Theology (Downer's Grove: IVP, 2008), 841-845.

5 De Gruchy, "South African Theology", 843.

6 See The Kairos Document. Challenge to the Church: A Theological Comment on the Political Crisis in South Africa, Second Edition (September 1986).

7 For a compilation of all kairos documents to date, see Gary S D Leonard (2010): Available online [internet] at: http://ujamaa.ukzn.ac.za/Libraries/manuals/The_Kairos_Documents.sflb.ashx [accessed 09/10/2010], 1-378. For a synopsis of its content and scope of application around the world, see Gerald West, "Kairos Documents: Mapping the Terrain” (Pietermaritzburg: Ujamaa Centre for Biblical and Theological Community Development Research), 1-24. Available online [internet] at: http://ujamaa.ukzn.ac.za/Libraries/Resources_for_consultation/An_overview_of_worldwide_Kairos_documents.sflb.ashx [accessed 18/03/2012].

8 See Dirkie Smit, "What does 'public' mean? Questions with a view to public theology" in Len Hansen (ed.), Christian in Public: Aims, Methodologies and Issues in Public Theology. Beyers Naudé Centre Series on Public Theology, Vol. 3 (Stellenbosch: African SUN Media, 2007), 11-46.

9 A moment of truth: A word of faith, hope, and love from the heart of Palestinian suffering (Kairos Palestine: 2009), 1-16. Available online [internet] at: http://www.kairospalestine.ps [accessed 25/01/2010].

${ }^{10}$ See Robert McAfee Brown, Kairos: Three Prophetic Challenges to the Church (Grand Rapids: Eerdmans, 1990), 9-12, who identified the following ten characteristics vis-à-vis the kairos documents:

They are written out of a sense of urgency; they are the result of a group process; they begin by analysing the present situation of oppression and pain; they accept the claim of theology as 'a second act', preceding an active engagement with and commitment to the poor and oppressed; they are informed theologically by social analysis; they are self-critical; they take the role of the church very seriously; they venture forth to name the enemy in order to locate major sources of sin and destruction in its public domain; they affirm hope as a major contribution of the gospel despite the heaviness of the social context; and, they conclude with great specificity in a variety of calls to action, pointing to immediate and practical steps that need to be taken. 


\section{Kairos Theology - and the public good?}

When I reflect on public theology, it is a way of drawing attention to the inherent public nature of Christian faith, the concern for the public dimension of Christian theology, the potential relevancy of theology beyond the ecclesial domain, and the intentionally public role of churches - indeed all notable components of our multifaceted perspectives and practices of public theology. In my understanding, the public theology discourse engages with the question of public responsibility amidst a history of overwhelming contradictions, ambiguities and complexities. ${ }^{11}$

The notion of 'public' in public theology should arguably not be reduced to simply meaning the opposite of 'private'. Nor ought it merely to become synonymous with 'social'. There is a fundamental sense of public theology lost when it receives these kinds of reductionisms, as being nothing more than 'relational theology' or 'social theology'. ${ }^{12}$ Another reductionist tendency has to do with 'public' being used interchangeably with 'contextual'. Public theology is indeed concerned with relationality, with sociality, and with contextuality - but it need not be reduced to any of these aspects, as important as they are concerning the nature and role of public theology. Perhaps a fourth reductionist issue relates to public theology being viewed as 'particularistic' in the same way liberation, political, black, feminist, womanist, African, minjung, dalit, and other so-called particularistic theologies are stereotypically regarded with particularity in mind. In this regard, some can mistakenly reduce public theology to being a particular North American discourse, while others can reduce it to being a particular theology in conflict with the relevant concerns of Latin American liberation theology or African womanist theology and the like.

Against the background of such forms of conceptual confinement, the notion of 'public' is important in my understanding and practice of public theology along two fronts. In the first place, I concur with those who underline the philosophical content behind what we today refer to as 'the public sphere', influenced in no small measure by the insights of Jürgen Habermas, who discusses the public sphere as a

${ }^{11}$ The following discussion draws from an earlier piece: Clint Le Bruyns, "Public Theology? On responsibility for the public good" (May 25th, 2011). Available online [internet] at: http://www.ecclesio. com/2011/05/public-theology-on-responsibility-for-the-public-good-\%E2\%80\%93-by-clint-lebruyns [accessed 25/05/2011].

12 For example, cf. an unpublished paper by Steve de Gruchy, "Introducing the Methodology of Social Theology" (June 2006). My criticism relates to at least two points. Firstly, he describes as 'social theology' what many of us functioning within the public theological discourse would understand as 'public theology' and, secondly, he describes as 'public theology' what many of us functioning within the public theological discourse would regard as a narrow - even fundamentalistic - conception of public theology. Regarding the latter point, he simply describes public theology as follows: "The study of an issue of public concern with a view to speaking to the 'public square' rather than the church, and that requires engagement with contemporary discourse in a secular and religiously pluralistic world. (e.g. Responding to 'gay marriages', teaching evolution, the death penalty)." 
distinctive, modern dimension of societal life characterised by communicative action through rational, participatory, transformational discourse ${ }^{13}$ Appreciating this philosophical texture concerning 'the public sphere' helps direct our attention in public theology not in general to relationality, sociality, contextuality or particularity, but more specifically to this 'public sphere'.

In the second place, then, this notion of 'public' helps us reflect more carefully on the concrete engagement of theology with the public sphere. Theology is in contact and conversation with concrete realms of public life - political, economic, civil society and public opinion. ${ }^{14}$ There are thus inevitable implications for understanding the agenda and mode of public theology. It is a way of understanding and practising theology which must contribute in constructive, dialogical, enriching and transforming ways to 'the public good'. ${ }^{15}$ For example, without dissolving the theoretical integrity of theological content, public theology demands of us a developing expertise in other disciplines of knowledge matched by a commitment to participate in conversations and exercises beyond the borders of a congregation or theological seminary.

Those of us schooled in such traditions as black theology or liberation theology affirm the agenda of 'the common good' as encapsulated in the role of theology in society. Others read this phrase narrowly as a Marxist ideological taint. Albert Nolan talks about "the coming of God's kingdom, God's reign on earth" as "the object of Christian hope" and, without losing perspective of the language of transcendence, talks about it more plainly than we typically do as theologians. ${ }^{16}$ "Our hope," he assumes, "is that God's will be done on earth" - and then concludes: "What God wills is always the common good. What God wants is whatever is best for all of us together, whatever is best for the whole of creation". ${ }^{17}$

The kairos theological tradition offers the South African and broader, global community a resourceful and challenging case study of the ambiguity that tends to characterise our theological perspectives and practices in relation to the common good. In reality we do not find it easy to appreciate what is best for everyone, concedes Nolan, since what we may often hope for are "too often selfish and self-serv-

${ }^{13}$ For a very detailed, critical discussion of this philosophical Habermasian content, see Smit, "What does 'public' mean?" 11-46. A more critical reflection on the reception of Habermas is part of ongoing discussion in places such as Brazil, South Africa, etc.

14 See Smit, "What does 'public' mean?" 11-46. Also Nico Koopman, "Some Comments on Public Theology Today" in Journal of Theology for Southern Africa 117 (November 2003), 9-10.

${ }^{15}$ For example, it "has more of a dialogical, cooperative and constructive approach", though one "that does not imply Constantinianism or patriotism". See Koopman, "Some Comments on Public Theology Today", 7.

${ }^{16}$ Albert Nolan, Hope in an Age of Despair (New York: Orbis, 2009), 7.

17 Nolan, Hope in an Age of Despair, 7-8. 
ing, egocentric and narrow-minded: hopes for a better future for myself, my family, my own country at the expense of other people; hopes for economic growth and a higher standard of living for some, regardless of others". ${ }^{18}$ "But if our attempts are to do, as far as possible, with whatever is for the common good, then we are doing God's will, and to that extent God's will is being done on earth". ${ }^{19}$

While public theology, drawing deeply from its different theological wells, attends to the agenda of the common good, I would suggest a more specific emphasis around this agenda, that of 'the public good'. This is to help us maintain the connection between theology and the public sphere with its political, economic, civil society and public opinion domains. ${ }^{20}$ The challenge of public theology is to assist us in humble and ambitious ways for taking responsibility to contribute meaningfully and concretely to the public good. Perusing the theological literature during South Africa's post-apartheid era, kairos theology as a brand of liberation theology does not appear to feature significantly in contributing to a liberation theology for our democratic society. Perhaps I could phrase it as such: kairos theology was important for the common good in the quest for liberation in the struggle against apartheid, but is arguably found greatly wanting in its resourcefulness for the public good in the quest for reconstruction and transformation in contemporary struggles.

\section{The rebirth of kairos theology?}

It is now a platitude to point out the fact that something happened to our theological paradigms during the post-apartheid era. Questions have been raised about our theological context, content, methodology and application. Some coin provocative

18 Nolan, Hope in an Age of Despair, 8.

19 Nolan, Hope in an Age of Despair, 8.

${ }^{20}$ Commenting on these realms and its implications for theological participation in the public discourse, Koopman provides the following summary statements: "The political sphere of the public focuses on themes relating to the relationship between theology and for example the state, government, political power and the control and regulating of public life. The economic sphere focuses on themes relating to the relationship between theology and for example the so-called autonomous market-economy, globalisation, ecology, science and technology. Civil society ... constitutes the third area of the modern public. This area focuses on themes relating to the relationship between theology and, for example, the institutions, organisations, associations and movements of civil society which, independently from the state and economy, strive to enhance the quality of life, satisfy the needs and foster the interests of people, change the nature of society and build the common good, that is life of quality for all. Schools, legal bodies, cultural and sports clubs and the neighbourhood are all institutions of civil society.... public opinion as the fourth sphere of the modern public ... focuses on themes relating to the relationship between theology and the pluralistic public discourse on, for example, the nature of society, common foundational values for society, common challenges and common priorities for society. The ensuing public opinion paves the way for jointly striving towards the common good". See Koopman, "Some Comments on Public Theology Today", 9-10. 
phrases to draw attention to some of these shifts. Steve de Gruchy suggested we moved from 'church struggle to church struggles' ${ }^{21}$ Charles Villa-Vicencio argued we moved from theologies of liberation to those of reconstruction. ${ }^{22}$ Etienne de Villiers talked about the move towards an ethics of responsibility. ${ }^{23}$ McGlory Speckman emphasised the move towards development. ${ }^{24}$ Isabel Phiri talked about a new concern for theologies of life..$^{25}$

The post-apartheid theological discourse in South Africa alerts us to the possibility (at least), or the reality (more frankly-speaking), that our theologies in the new South Africa may not necessarily be as appropriate and responsive as we would like for the kind of public impact and critical participation that the times demand. I think this is why in various quarters in more recent years we are revisiting the South African Kairos Document and our kairos theological tradition. We do not appear to be fully confident that we have a public theology evidencing these much-needed dimensions of contextuality, criticality and change.

In December 2009 the Palestinian Kairos Document was released. It stood in line within this great kairos theological tradition, itself inspired by the South African Kairos Document. ${ }^{26}$ Palestinian Christians cried out to the ecumenical church and international community about their ongoing suffering under Israeli occupation and apartheid coupled with the deafening silence of the international community of believers and nations. ${ }^{27}$ They drew special attention to the destructive public impact of the ways in which biblical and theological resources were being employed. ${ }^{28}$

A month later a group of South African church leaders and theologians began the process of formulating a document that could serve as a South African response to the Palestinian struggle with its issues of occupation, apartheid and Zionism. As part

${ }^{21}$ See Steve de Gruchy, "From church struggle to church struggles" in John de Gruchy with Steve de Gruchy, The Church Struggle in South Africa. 25th Anniversary Edition (London: SCM, 2004), 223-260.

22 See Charles Villa-Vicencio, A Theology of Reconstruction: Nation Building and Human Rights (Cambridge: Cambridge University Press, 1992); "Beyond Liberation: A New Theology for South Africa" in Challenge Magazine (1993), 24-25; "Liberation and Reconstruction" in C Rowland (ed.), The Cambridge Companion to Liberation Theology (Cambridge: Cambridge University Press, 1999), 153-175.

${ }^{23}$ See, for example: Etienne de Villiers, "A Christian Ethics of Responsibility: Does it provide an adequate theoretical framework for dealing with issues of public morality?" in Scriptura 82 (2003), 23-38; D E De Villiers, "Human rights and moral responsibility: Their relationship in the present South African society" in Ned-Geref Teologiese Tydskrif 141: $3 \& 4$ (2000), 212-224.

${ }^{24}$ For example, see: McGlory T Speckman, A Biblical Vision for Africa's Development? (Pietermaritzburg: Cluster Publications, 2007).

${ }^{25}$ As an example, see Isabel Apawo Phiri, "HIV/AIDS: An African Theological Response in Mission" in Kwok Pui-lan (ed.), Hope Abundant: Third World and Indigenous Women's Theology (New York: Orbis, 2010), 219-228.

${ }^{26}$ A moment of truth, http://www.kairospalestine.ps, 2.

${ }_{27}$ A moment of truth, http://www.kairospalestine.ps, 2 and 4-6ff.

${ }^{28}$ A moment of truth, http://www.kairospalestine.ps, 6ff. 
of this group I recall how much this process of reading the Palestinian Kairos Document and attempting a South African response forced us to ask questions about our own life-situation and the public role of theology and church. It pushed us to revisit our own Kairos Document and the quality of public theology for liberation, justice and dignity it envisaged and called for. I remember how much the Palestinian Kairos Document seemed to be helping us reconnect with our South African context and to review the state of prophetic public theology in the church, academy and society. The process underlined these aspects of contextuality, criticality and change. In the end we submitted a response to Kairos Palestine in April 2010, at the time of Easter, with the support of more than 60 key church leaders and theologians. ${ }^{29}$

A month later, in May 2010, the South African Council of Churches held a consultation in Kempton Park on the Palestinian Kairos Document. A number of stalwarts of the kairos theological tradition were present, including Frank Chikane and Allan Boesak. I, along with several others, presented critical input on the situation in Palestine-Israel, the Palestinian Kairos Document, and the need for solidarity with Palestinians. In retrospect, our input did not generate much discussion about Palestine-Israel itself - as it did about South Africa today. What the ecumenical leaders and theologians really used the occasion to talk about was the kairos theological tradition and the need to revisit it for its relevance in regard to our public challenges and public responsibility in South Africa.

A few months later, in October 2010, many of us gathered in Pietermaritzburg for the 25th anniversary of the South African Kairos Document. ${ }^{30}$ Besides 'looking back' during the commemoration, what resurfaced throughout were the aspects of contextuality, criticality and change. People were fatigued, overwhelmed and despairing of the numerous public challenges they confronted as persons in communities. People were by no means politically-correct in their tone, view and assessment of the political and other powers in public life; on the contrary, they were frustrated, angry and critical. They were extremely critical of the church and theology as public role-players for transformation in political, economic and cultural life. There was indeed a deep sense of nostalgia (cf. painful longing) for the quality of theological engagement as was evident in the kairos theological tradition. In fact, among us were again some of the stalwarts of the kairos theological tradition,

29 "A South African Christian Response to the Palestine Kairos Document" (Easter 2010), 1-9. Available online [internet] at: http://www.kairospalestine.ps/sites/default/Documents/From\%20South\%20 Africa\%20to\%20Palestine.pdf [accessed 17/04/2010].

${ }^{30}$ For a report of the commemoration and consultation, see "Report on the Ujamaa Centre's 21st Anniversary and Consultation - 'A luta continua: connecting prophetic voices'. Available online [internet] at: http://ujamaa.ukzn.ac.za/Libraries/manuals/Ujamaa_celebration_and_consultation_report_1.sflb.ashx [accessed 06/11/2010]. 
such as Itumuleng Mosala, who displayed much scepticism and negativity regarding the public contribution of theology in contemporary South Africa. Others, such as Albert Nolan and Allan Boesak, presented scathing criticisms of the political and economic powers from a theological perspective. Discussion by these and other thinkers assisted us around questions of social analysis and the weaknesses of the churches and their theologies. In general, though, our deliberations offered less direction around the future of theology and church as constructive role-players in transforming public life for the common good.

There have been a number of related initiatives and events that I've participated in since then. A common thread has been celebrating and revisiting our kairos theological tradition. Progressively the question of an organised movement with a 'kairos consciousness' ${ }^{31}$ surfaced. Eventually the establishment of 'Kairos Southern Africa' was born early 2011.

These individual and collective initiatives have convinced me about the emerging rebirth not so much of a kairos theology, but of a kairos theological tradition with its kairos consciousness marked by contextuality, criticality and change. I would suggest that those of us who are active role-players and thought leaders within various theological paradigms - black theology, liberation theology, womanist theology, feminist theology, confessing theology, African theology, public theology, etc. - must take cognisance of this apparent 'rebirth' of kairos consciousness and seriously consider what implications and responsibilities it presents to us in present-day South Africa as public theologians in one way or another.

\section{Kairos Theology - and the future of public responsibility?}

It has become increasingly evident that a kairos consciousness needs to be regained with its aspects of contextuality, criticality and change. As an example of this in action, I want to direct our attention to the recent document of December 2011 submitted by Kairos Southern Africa to the African National Congress at the occasion of the launch of its centenary celebrations. ${ }^{32}$ It takes the form of a letter, structured by way of 17 'words' from the churches to the ruling party. At the time of its submission, the letter was endorsed by about 100 church leaders, theologians and concerned people, including those beyond the Christian or religious realm, who all identified with the message of Kairos Southern Africa. As one who was consulted about its contents and as a signatory, it is remarkable to observe how seriously this letter was taken by the ANC and the strong support it has thus far received from

${ }^{31}$ See Allan Boesak, “Kairos Consciousness” (March 25th, 2011). Available online [internet] at: http:// kairossouthernafrica.wordpress.com/kairos-consciousness [accessed 18/05/2011].

${ }^{32}$ Available online [internet] at: http://kairossouthernafrica.wordpress.com/2012/03/06/kairos-logo [accessed 14/01/2012]. 
the public, with a 1-million-signature campaign presently in motion. The 17 words of the letter could be reduced to 4 words: celebration, confession, collaboration, critique. The Kairos Southern Africa letter holds importance as an attempt to regain a kairos consciousness among ordinary people. There is the sense of an increasing disconnect between the people and the powers, and between the people and democratic life together; this is being addressed to some extent in this letter.

The question of a participatory democracy or active citizenship remains a pressing matter for public theology in South Africa. ${ }^{33}$ The notion of 'participatory democracy' or 'active citizenship' is in political vogue in and beyond South Africa today. It has become a way of talking about the responsibility all people must assume for the integrity and advancement of their life together. Initiatives of Theological Projects such as Kairos Southern Africa ${ }^{34}$, the Beyers Naudè Centre for Public Theology at Stellenbosch University ${ }^{35}$, or the Theology and Development Programme at the University of KwaZulu-Natal ${ }^{36}$, are all notable cases in point of an attempt at a public or social theology embedded in a kairos consciousness directed towards a responsible citizenship ethic.

\section{An ethic of responsible citizenship?}

The public discourse on citizenship revolves around important questions of identity and human dignity, agency and power, and public responsibility. ${ }^{37}$

This notwithstanding, at least two preliminary points should be made. The first issue is that we acknowledge that this discourse is neither neutral nor uncontested. We should not be naïe and ignorant about its perceived ideological nature, how it might be employed for specific political and economic agendas, and the possible popular resistance to it. Moreover, an ideal of citizenship might not even be desirable; political and economic powers can deliberately discourage it.

A second issue has to do with the tendency of a conceptual narrowness in how it is understood, an issue current literature on citizenship bemoans. The notion of citizenship underlines the call for a new kind of politics, a different quality of

${ }^{33}$ Some previous reflection on this subject can be found as follows: Clint Le Bruyns, "Responsabilidade libertadora para a transformação moral? Sobre o papel dos movimentos sociais e suas implicações para a teologia pública na África do Sul hoje" in Ronaldo Cavalcante and Rudolf von Sinner (Orgs.), Teologia Pública: Em debate (São Leopoldo/RS, 2011), 85-105.

${ }^{34}$ See http://kairossouthernafrica.wordpress.com/

${ }^{35}$ See http://www.beyersnaudecentre.org/

${ }^{36}$ See http://theologyanddevelopment.ukzn.ac.za/

${ }^{37}$ See the theological framework developed by Rudolf von Sinner, "Citizenship in the Brazilian Context theoretically, practically and theologically", vis-à-vis dignity and rights; trust in the context of distrust; the ambiguity of existence; liberty and service; and serving one God under two regiments. For more extensive discussion, see Rudolf von Sinner, The Churches and Democracy in Brazil: Towards a Public Theology Focused on Citizenship (Eugene: Wipf \& Stock, 2012), especially 68-99 and 281-317. 
life together. It is understandable why the idea of a more 'critical' citizenship is in vogue. Literature on citizenship demands a more transcendent view of this concept, a perspective that goes beyond such paradigms as 'indigenous politics', 'party politics', 'state politics', and 'imperialist politics'. These aspects undergird the need for an ethic of responsible citizenship. ${ }^{38}$

In order to offer some orientation and content to an ethic of responsible citizenship, I want to propose the following framework: First, kairos consciousness as a vision of change; second, kairos consciousness as a virtue of criticality; and third, kairos consciousness as a practice of contextuality.

\subsection{Public theology for responsible citizenship: Vision of change}

A few years ago, on a beautiful Sunday afternoon, I took a stroll down the streets of the university section of central Stellenbosch. At that time I was working in Systematic Theology at Stellenbosch University's Faculty of Theology. As I walked past the Faculty of Education building, a team of workers were positioning a very large banner above the entrance of the building. It read: "Education...can change the world." I thought to myself, "How inspiring! And that's something a theologian would say." Moments later I reached the Faculty of Law building. There another team was hard at work with a similar banner, except that this time it read: "Law... can change the world." What was going on in Stellenbosch? Banners of this type were being placed above the entrance to every Faculty building. Indeed, on reaching my own Faculty, there was the banner: "Theology...can change the world." I could only imagine how surprised and intrigued these university students would be as they rushed (or staggered!) to Monday morning classes the next day, to be confronted with this critical connection between their particular science and the life-giving agenda of social transformation and public responsibility.

José Galizia Tundisi in an essay on "The Advocacy Responsibility of the Scientist" offers several statements about the interconnection between science (in a broadbased sense) and social transformation..$^{39}$

First, he emphasises the fundamental importance of knowledge in the world of science, "that scientists from all walks of life have the task of promoting and in-

${ }^{38}$ See Clint Le Bruyns, "The Church, Democracy and Responsible Citizenship" in Religion \& Theology 19:1-2 (2012), 60-73; Clint Le Bruyns, "The Church, Democracy and Responsible Citizenship" in W Bentley and DA Forster (eds), Between Capital and Cathedral: Essays on Church-State relationships (Pretoria: Unisa, 2012), 57-71. These publications are based on my research that emerged out of a research collaborative partnership between EST Faculdades (Brazil) and Stellenbosch University (South Africa) during the period 2009-2012.

${ }^{39}$ José Galizia Tundisi, "The Advocacy Responsibility of the Scientist" in Kathleen Dean Moore \& Michael P Nelson (eds), Moral Ground: Ethical Action for a Planet in Peril (San Antonio: Trinity University Press, 2010), 448-451. 
creasing knowledge through their professional activities". ${ }^{40}$ Without deflecting from an understanding of theology that is 'lived' and 'experienced', he indirectly reminds us of a theology that is also 'thought' and 'known'. It is thus quite appropriate even essential - that we still behold theology as a science, concerned with different rationalities, conceptualisations and discourses.

Second, he contends that while the world of science readily contributed to social progress in a variety of realms and ways during the past century, scientists in the twenty-first century "face a different problem" and that "the world needs science and scientists in a very different way". ${ }^{41}$ Tundisi is thinking more specifically about the ecological challenges confronting us today as that 'different problem'. His implied point is double-edged: On the one hand, the world of science continually makes us aware of new challenges calling forth public responsibility; on the other hand, the world of science continually needs to be open to modification and reform in order to better advance social wellbeing. A credible world-affirming public theology would, therefore, be one that continues the liberational paradigm of taking social analysis and kairos consciousness seriously coupled with a self-critical, re-forming nature. We need to think and do theology in ways that facilitate conscientisation about existential realities and in ways always open to critique and reformation.

Third, Tundisi underlines the transformative responsibility within the world of science. He asks: "Given this reality, this reality of which science has made us aware, how can we scientists, we gatherers and disseminators of knowledge, help to change this course of events? What is our role in remediation?" ${ }^{42}$ His line of questioning disturbs the stereotypical myth of what I'd refer to as 'a dusty consciousness' - a knowledge relegated to dusty bookshelves. On the contrary, his expectation of science is that it must be responsive to that about which it has made us aware. The quality of public theology required today cannot simply 'pass on' in a 'repetitive' fashion dogmas of the past; rather, it must help us engage with and change social realities for a better life for all being.

Fourth, it thus follows that "striving to understand the world and then disseminating our findings to the public is more important than ever". ${ }^{43}$ He hereby picks up on the necessity for public reception. It is not sufficient that the world of science attests to these aforementioned features; it demands reception, ownership and participation throughout the public arena where politics, economics, civil society and public opinion interconnect. Science thus moves from vision to action. The relevance for public theology is that, indeed, our theological capital for the constructive transformation

40 Tundisi, "The Advocacy Responsibility of the Scientist", 448.

41 Tundisi, "The Advocacy Responsibility of the Scientist", 448.

${ }^{42}$ Tundisi, "The Advocacy Responsibility of the Scientist", 449.

${ }^{43}$ Tundisi, "The Advocacy Responsibility of the Scientist", 449. 
of life must not remain stuck within the ecclesial quarters or among the professional elite of the churches, but must most certainly be 'received' by the broader community of people. Furthermore, our theological contributions must transcend mere visionary activity; it must extend to broader aspects of our life together, such as the domains of public policy, international law, political practice, economic ideologies, and so on. While an extremely complex and admittedly controversial arena of public theological engagement, theology at its best envisions, embodies and advances the public good.

Fifth, Tundisi argues for science as "a method for social transformation" which "can be an integral part of the noble work to improve the quality of life". ${ }^{44}$ This underlines the actual impact of science on everyday life. To what degree does it impact life in actual, concrete, constructive ways? Similarly, the connection between theology and social transformation must be actually experienced, as opposed to merely sought after or anticipated. To the extent that churches and theologians influence public policy or political law for the betterment of life for all, therein lies its eventual nobility as a public science.

Sixth, Tundisi then concludes on a hopeful note: As an ecological scientist, he says, "I am convinced that our moral responsibility and our engagement with society can help to save our planet". ${ }^{45}$ His essay, albeit modestly, appeals for a consideration of a science of hope, or of scientists of hope. Theologies of hope feature pre-eminently within the Christian theological tradition, and is receiving renewed attention today in the light of a vast array of despairing challenges ${ }^{46}$ Once again the litmus test rests with ordinary people confronting social, existential realities who will respond with either despair or hope based on what kind of public reception and impact our theology brings to our life together.

\subsection{Public theology for responsible citizenship: Virtue of criticality}

The idea of public theology today is a contested notion. There is the obvious story of ambiguous public theological conception and engagement during apartheid South Africa; the South African Kairos Document of 1985 confronted us about this ambivalence and its very life-and-death implications. State Theology proponents exercised destructive public theology, a legacy part and parcel of our continuing social baggage. Church Theology representatives reflected an impotent, indifferent, selfcentred public theology, which preserved the status quo. Prophetic theology advocates were committed to a prophetic public theology that could discern, confront,

${ }_{44}$ Tundisi, "The Advocacy Responsibility of the Scientist", 449.

${ }^{45}$ Tundisi, "The Advocacy Responsibility of the Scientist", 451.

${ }^{46}$ For example, see Selina Palm, "Transforming Hope? A Theological-Ethical Vision, Virtue and Practice for the Common Good” (Unpublished MTh thesis, Stellenbosch University, March 2012), at Internet: http://scholar.sun.ac.za/handle/10019.1/20135 [accessed 18/04/2012]. 
oppose, struggle, revolutionise, perhaps even transform. ${ }^{47}$ Against the background of our historical narrative, it behoves us to indeed be discerning and cautious about this idea of so-called public theology.

The narrative of Abahlali baseMjondolo is an intriguing, insightful and instructive narrative for exploring the challenges of responsible citizenship, along with the role of the churches in their various forms and manifestations. ${ }^{48}$ In a cursory study, I would highlight the following findings for further reflection and deliberation:

1. The question has come up as to how Abablali baseMjondolo (AbM) should or could relate to the churches. So far, AbM has sometimes approached churches, and more and more, AbM is being approached by church people and church-based organisations. But the churches are complex, and they might have their own, different agendas and possibilities in relation to AbM's struggle.

2. The discussions responded to the following 2 questions. First, "What are our experiences of the church in our struggle so far?", and second, "What do we need from churches?"

3. So far, in the struggles of the AbM, there has only been a loose connection with churches and it has not been well-defined. It has really only arisen from time-to-time in response to incidences of tragedy.

4. But beyond these tragedies and crises, there has been no time really to celebrate liturgy in our place together with church people, and nor have we had a constructive workshop to talk about these things properly before now. Because of this loose connection, the church doesn't know about our life in the shacks, it has no experience of it. Because it has not been present, the church does not know about the difficulties that the people go through and it does not know about the crises we face ... and so, the church does not feel our pain.

5. Because of this loose connection too, the church is not here with us to pass on important moral principles that are about how it is to be human beings - the church is not here with us.

6. This distance is not healthy. The tragedies that happen here in the shacks, and the knocking down of people's houses, can put people onto the streets. Surely in these cases, the churches could even provide temporary shelter?

7. But more than that, church ministers are people that others are prepared to listen to and so, if they were there with us, then it is possible that their

${ }^{47}$ See Clint Le Bruyns, "Religion and the Economy? On Public Responsibility through Prophetic Intelligence, Theology and Solidarity" in Journal of Theology for Southern Africa 142 (March 2012), 80-97.

${ }^{48}$ Here some basic historical background remarks can be made. See http://abahlali.org 
presence could even stop demolitions from going ahead. And if we from AbM and the churches grew closer together, it is possible that we might start learning better about what they believe - for now, we don't really know.

8. But even this weak connection that we are discussing, and what we have said already, shows that we need each other and that we need to make our voices stronger together because it is important to build a common struggle. For a long time in our struggles, many people looked down on us because we are from the shacks, they think of us almost as if we are criminals who prey on others. But our recent connection with the Bishop makes us think that some people are thinking hard and seriously about our experiences, and they do not just assume we are a bunch of wortbless hooligans. That our struggles are taken seriously by respected people is important.

9. In addition, these respected people in the churches have connections overseas, and maybe they could help with some of the immediate crises of poverty that affect people in the shacks.

10. Although we ask the question about 'what do we need from the churches?' we must start from the position that we must work together. We must acknowledge that we are together actually because, inside the church, we have women, children, people who are from the jondolos - so why do we disconnect the 'Sunday church' from the day-to-day life and struggle AbM? This '2-in-1' division must be discussed and the two aspects must be made to complement each other.

11. We acknowledge that the government is a very bad listener to the poor. But it listens to the churches. So maybe we can use that to add to the strength of our voice. Perhaps church leaders can use their status to persuade the government on our issues. How would it be if church leaders joined us in our marches - wouldn't that make the government listen more? The church leaders give their support to many important public awareness campaigns (for example regarding the protection of children's rights, or the fight against crime) and this is because sometimes people are prepared to listen when church people say things. Looking at the poster on the wall of our meeting room here about the churches supporting the call for an 'HIV/AIDS free generation', perhaps there is a challenge to the churches to launch a new awareness campaign for a 'shack-free generation'. We have seen in our experiences that, sometimes when people were losing their rights - for example to their land - that some priests and churches stepped in to stop it, or at least to provide help.

12. This discussion makes us think not only about the church out there. It is starting to revive the religious person in us and we are beginning to wonder, 
'what is our religious belief?' - if we are God's children, then what does this mean for us living in the shacks? And what does it require us to do?

13. We know that church is the closest place to the people because a church is not a church without people. And so the people know it as the most recognised place - aplace of safety, where there are no thieves and others who prey on us. So we have this feeling about the church that everyone has a 'willingness' to support and give dignity. We are nobody without the church. Somehow in this way, the church can be a bridge between AbM and the government because it will be seen that we are not animals. And then nothing is impossible.

14. In the history of South Africa, before 1994 and at the peak of mobilisation and unrest, we saw some religious figures playing a role. But discrimination, racism and apartheid are not over! Now apartheid is between those who are rich and those who are poor, and we see that this apartheid is getting worse. This should make the church to be uncomfortable and therefore, the need for their intervention is just as important now as it was then - and they cannot do it on their own, they must work with the movements of the poor.

15. There is a perception that religious people are trustworthy. As we come from the shacks, we are not trusted. Even our churches from the shacks are not trusted.

16. When we look at charity and relief work like feeding schemes, it is better when these come from churches than from political parties because when it comes from the political parties it is actually like a 'bait', something is expected from us in return. And also, if the churches were involved in this kind of work, then they would know about how our life is, which is important.

17. There are statements in the Bible that are important.

18. Churches are meant to be agents of justice. They understand that unity is important in some of their own work, and in different areas they are joining together to work better. This approach should also apply in connection with social movements and justice.

19. There seem to be many possibilities that can be developed between the struggles of AbM and the churches. But, we are also not naïve about the churches. We know that some parts of the church pray with the rich and powerful people, that some parts of the church continue to give their blessing to this government. But although the church has these problems, we are sure that God is on the side of the poor.

Public theological engagement is myopic, fantasaic and impotent when it merely engages with people, institutions and structures of power, as opposed to also engaging with social movements and grassroots initiatives. This, I would argue, is a present weakness in public theological engagement in South Africa through such initiatives 
as Kairos Southern Africa and related public theological projects. In this way, a 'critical edge' is lost or veiled, to the detriment of the public witness of the church and theology in advancing an ethic of responsible citizenship.

\subsection{Public theology for responsible citizenship: Practice of contextuality}

We cannot take it for granted that theologians in post-apartheid democratic South Africa find it acceptable, or at the very least accept it uncritically. Whereas some scholars embrace this notion quite explicitly for its appropriateness and resourcefulness in how they conceive of the public nature, rationality and impact of theology (for example, E de Villiers, N Koopman, C Le Bruyns, D Smit, V Vellem), others engage with it more soberly and conditionally (for example: A Boesak, J Cochrane, $\mathrm{J}$ de Gruchy, S de Gruchy, R Tshaka), while still others ignore or respectfully dismiss it as not being a helpful or relevant way of making sense of theology and its role in our social life together (for example: T Maluleke). The critical questions these scholars raise are extremely important and thus indeed valid.

Broadly speaking I would venture to say that there tends to be two dominant categories of contestation. First, there is a disagreement or reservation on typological grounds. ${ }^{49}$ Here scholars criticise a view of public theology narrowly restricted to theologies of (re)construction following pre-liberation protest and struggle. A distinction is made between theologies of protest and theologies of reconstruction. It implies that complex issues of protest and struggle are overcome or not as relevant within a new democratic milieu. The new context has seemingly made oppositional theologies unnecessary and inappropriate. Construction rather than confrontation is the assumed mode of engagement. It is a public theological engagement which ultimately makes space for those of high power and influence, and denies meaningful participation by those limited or lacking in democratic public agency. The problem of this conception of public theology is its constricted model of publicness.

Second, there is a disagreement or reservation on ideological grounds..$^{50}$ Here scholars criticise a view of public theology oblivious to local, contextual, post-colonial dynamics. It speaks too abstractly, generally and universalistically about public theological engagement, in so doing positing an overarching theological paradigm into which everything must fit. It ignores the regional and parochial nature of theology, thereby painting a "rather benign, metropolitan and even romantic" notion of public life. It dismisses local theologies such as black theology, African theology, women's theology, and liberation

49 James R Cochrane, "Against the Grain: Responsible Public Theology in a Global Era” in International Journal of Public Theology 5 (2011), 44-62.

50 Tinyiko Sam Maluleke, "Reflections and Resources - The Elusive Public of Public Theology: A Response to William Storrar" in International Journal of Public Theology 5 (2011), 79-89. 
theology. It dismisses critical historical dimensions such as postcoloniality. The problem of this conception of public theology is its acontextual model of publicness.

In another essay, Maluleke underlines the fact that when we think of South Africa simply as 'a young democracy' it is to our peril..$^{51}$ It's a misnomer, he contends. He argues for a consciousness of post-colonial life as a life still grappling with life as a colony. The complex and conflicting dynamics of power, identity and alienation are ever-present. Maluleke appreciates the need for many in the public theology domain to emphasise theories of reconstruction, but asserts that there can be no meaningful constructive theory without a meaningful theory of resistance. I find his contention valid. However, for the purposes of public theological engagement towards social transformation, his argument is true in what it affirms but unhelpful in what it denies. The post-colonial, post-apartheid, democratic South Africa demands an ethics of resistance, but it must be conceived along with an ethics of reconstruction. It seems as if Maluleke reduces construction to co-option or uncritical cooperation with the powers. Do we not need a public theological engagement that can protest, resist and oppose at the same time as it seeks to contribute to the reshaping of our life together? Or are we called to simply remain 'watchdogs' of society, instead of critical, prophetic participants in public transformation as well?

A public theology expressive of such a sanitised and acontextual nature is a public theology not worthy of its name. However, one of my contentions with these scholars who contest the notion of public theology concerns the ironic fact that, possibly unknowingly, they make voices outside of South Africa - in the 'North' - the determinants as to what public theology is all about. Their point of departure revolves around public theology advocates outside of South Africa. Advocates of public theology within South Africa are then left to defend the charges. They criticise North American and European representatives of public theology, but draw general conclusions for us all about the meaning and appropriateness of public theology. Why do they base their assessments simply on these sources? Should they engage critically with sources within South Africa, would their assessment be the same? Would they necessarily find public theology advocates who view public theology as a replacement of liberation theology? Would they find us guilty of discarding local historical, post-colonial dynamics of power and transformation? Would they really discern a way of doing theology with no traces of a black liberation theology?

At the same time, it is on this point of contextuality that public theological engagement must be examined for its relation to ordinary peoples' movements, such as Abahlali. A kairos consciousness is rooted in a people's theology.

${ }^{51}$ Tinyiko Sam Maluleke, "May the Black God Stand Please!: Biko's Challenge to Religion" in Andile Mngxitama, Amanda Alexander \& Nigel C Gibson (eds), Biko Lives! Contesting the Legacies of Steve Biko (New York: Palmgrave Macmillan, 2008), 115-126. 


\section{A concluding note}

I conclude with a poem by Zolani Mkiva, an imbongi yesizwe, who hails from Idutywa in the Eastern Cape. His poem "Son of the Soil" (1974) leaves us with the challenge of rootedness in Africa and the option of transcendence.

I do not have perfumed lips

But I speak the truth

I do not have cat eyes

But I can see the true colours of the universe

I do not have donkey ears

But I can hear what make sense and what is a nuisance

I do not have a dog nose

But I can smell and distinguish between carbo-monoxide \& oxygen

I do not have a big heart

But I do have passion for love and I love people

I do not have soft hands

But I can deliver my people from shame

I am the son of the soil

Like daughters of the land

I am the filament of freedom

I am the pistil of peace

I am the calyx of consciousness

I am the corolla of peoples cause

I am the pollen of prosperity

I am the anther of amicable solutions

I am the stem of our society

The son of the soil

The public theology to which I am committed is a public theological engagement that seeks to draw from the African soil and to dream of overcoming all that oppresses and dehumanises. All in all, a public theology embedded in a kairos consciousness of contextuality, criticality and change towards the nurturing of a responsible citizenship. 